\title{
Renal Cell Carcinoma Associated with Neuroblastoma
}

National Cancer Institute

\section{Source}

National Cancer Institute. Renal Cell Carcinoma Associated with Neuroblastoma. NCI

Thesaurus. Code C100051.

Renal cell carcinoma that develops in patients who are long-term survivors of childhood neuroblastoma. 